\title{
UPAYA MENINGKATKAN AKTIVITAS DAN HASIL BELAJAR IPA SISWA MELALUI PENERAPAN MODEL PROBLEM BASED LEARNING (PBL)
}

\author{
Melly Safitri ${ }^{1 *}$, Yennita ${ }^{1}$, Irdam Idrus ${ }^{1}$ \\ ${ }^{1}$ Program Studi Pendidikan Biologi, Fakultas Keguruan dan Ilmu Pendidikan, Universitas Bengkulu \\ Email: mellysafitri699@gmail.com
}

\begin{abstract}
ABSTRAK
Penelitian ini bertujuan untuk mendeskripsikan aktivitas mengajar guru, aktivitas belajar siswa dan meningkatkan hasil belajar siswa dengan menggunakan model Problem Based Learning (PBL) di kelas $\mathrm{VII}_{2}$ SMP Negeri 14 Kota Bengkulu, pada materi Dampak Pencemaran Bagi Kehidupan. Jenis penelitian ini adalah Penelitian Tindakan Kelas dengan metode deskriptif. Penelitian ini terdiri dari dua siklus, masing-masing siklus terdiri dari 4 tahap yaitu: tahap perencanaan, pelaksanaan, pengamatan dan refleksi. Subjek penelitian ini adalah seluruh siswa kelas $\mathrm{VII}_{2}$ SMP Negeri 14 Kota Bengkulu tahun ajaran 2016/2017, sedangkan peneliti berperan sebagai guru. Variabel penelitian ini adalah model Problem Based Learning (PBL), aktivitas mengajar guru, aktivitas belajar siswa dan hasil belajar siswa. Teknik pengumpulan data dalam penelitian ini yaitu observasi dan tes. Hasil analisis data aktivitas guru siklus I diperoleh skor rata-rata yaitu 30,3 (Baik), dan pada siklus II skor aktivitas guru menjadi 31 (Baik). Hasil analisis data aktivitas siswa pada siklus I diperoleh skor rata-rata 30,3 (Baik), dan pada siklus II skor aktivitas siswa menjadi 30,6 (Baik). Selanjutnya data hasil belajar siswa pada siklus I dianalisis berdasarkan kriteria ketuntasan belajar klasikal dan diperoleh persentase ketuntasan belajar klasikal yaitu $82,3 \%$ yang termasuk kedalam kriteria belum tuntas dan pada siklus II hasil belajar siswa mengalami peningkatan dengan ketuntasan belajar klasikal yaitu $85,2 \%$ dan termasuk dalam kriteria tuntas. Dari hasil penelitian dapat disimpulkan bahwa model Pembelajaran Problem Based Learning (PBL) dapat meningkatkan aktivitas guru dan aktivitas siswa serta hasil belajar siswa kelas $\mathrm{VII}_{2}$ SMPN 14 Kota Bengkulu.
\end{abstract}

Kata Kunci: Problem Based Learning, aktivitas belajar, hasil belajar

\begin{abstract}
This study aimed to described teacher's teaching activity, student activity and improved student learning outcomes by using Problem Based Learning (PBL) model in class $\mathrm{VII}_{2}$ SMP Negeri 14 Bengkulu city on topic The Impact of Pollution for Life. This research was a classroom action research with descriptive methods. The study consist of two cycles, which each cycle consist of four phases: planning, implementation, observation and reflection. The subjects were all students in grade $\mathrm{VII}_{2} \mathrm{SMP}$ Negeri 14 Bengkulu City 2016/2017 school year, while the researcher act as teacher. The variables of this research were Problem Based Learning (PBL) model, activity of teacher teaching, student learning activities and student learning outcomes. Data collection techniques in this study were observation and tests. Data analysis of teacher activity in first cycle resulted score average 30,3 (Good), and in second cycle was 31 (Good). Data analysis of student activity in first cycle resulted score average 30,3 (Good), and in second cycle was 30,6 (Good). Furthermore data of student learning outcomes in first cycle was analyzed based on criteria of classical learning completeness and resulted the percentage of classical learning completeness was $82,3 \%$ which was categorized as uncomplete criteria, while in second cycle was $85,2 \%$ which was categorized as completed criteria. This research concluded that Problem Based Learning Learning (PBL) model increased teacher activity, student activity and student learning outcomes on class VII2 SMPN 14 Bengkulu.
\end{abstract}

Keywords: Problem Based Learning (PBL), learning activity, learning outcomes 


\section{PENDAHULUAN}

Pendidikan merupakan usaha sadar dan terencana untuk mewujudkan suasana belajar dan proses pembelajaran agar peserta didik secara aktif mengembangkan potensi dirinya untuk memiliki kekuatan spiritual keagamaan, pengendalian diri, kepribadian, kecerdasan, akhlak mulia, serta keterampilan yang diperlukan dirinya, masyarakat, bangsa, dan negara sebagaimana termaktub dalam Pasal 1 ayat (1) Undang-Undang Nomor 20 Tahun 2003 tentang Sistem Pendidikan Nasional (Permendikbud, 2014).

Belajar adalah proses perubahan tingkah laku individu sebagai hasil dari pengalamannya dalam berinteraksi dengan lingkungan. Belajar bukan hanya sekedar menghapal, melainkan suatu proses mental yang terjadi dalam diri seseorang. Sedangkan pembelajaran pada hakikatnya merupakan suatu proses interaksi antara guru dengan siswa, baik interaksi secara langsung seperti kegiatan tatap muka maupun secara tidak langsung (Rusman, 2014).

Berdasarkan pengamatan awal dan diskusi dengan guru IPA di kelas $\mathrm{VII}_{2}$ SMPN 14 Kota Bengkulu tahun ajaran 2016/2017 yang dilakukan oleh peneliti pada bulan Januari 2017 terhadap pembelajaran di kelas, masalah pembelajaran pada siswa di kelas adalah aktivitas dan hasil belajar siswa yang kurang maksimal. Ini terbukti dari rerata nilai hasil belajar IPA siswa kelas $\mathrm{VII}_{2}$, dari 34 orang siswa hanya 18 orang yang mencapai ketuntasan minimal. Kriteria Ketuntasan Minimal (KKM) di SMPN 14 Kota Bengkulu adalah $\geq 75$ dengan ketuntasan belajar klasikal $\geq 85 \%$, berarti hanya 52, $94 \%$ (18 orang) siswa kelas $\mathrm{VII}_{2}$ yang tuntas belajar IPA secara klasikal, sementara harapannya nilai hasil belajar dapat lebih meningkat pada tiap- tiap siswa dan 85 \% siswa dengan nilai $\geq 75$.

Masalah tersebut perlu diatasi dari aspek pengetahuan dan pembelajaran. Dari aspek pengetahuan adalah untuk meningkatkan hasil belajar siswa sehingga $85 \%$ siswa memperoleh nilai $\geq 75$. Selain itu masalah tersebut juga perlu diatasi terkait dengan tujuan pokok penyelenggaraan kegiatan pembelajaran yaitu membelajarkan siswa agar mampu memproses dan memperoleh pengetahuan, keterampilan, dan sikap bagi diri sendiri. Siswa diharapkan dapat memperoleh hasil yang baik dari proses pembelajaran tersebut. Berdasarkan Permendikbud no. 54 tahun 2013, salah satu standar kompetensi lulusan yang diharapkan adalah memiliki kemampuan pikir dan tindak yang efektif dan kreatif dalam ranah abstrak dan konkret sebagai pengembangan dari yang dipelajari di sekolah secara mandiri. Hal ini berarti siswa harus memiliki kemampuan berpikir termasuk diantaranya adalah kemampuan memecahkan masalah yang dapat meningkatkan hasil belajar siswa di kelas.

Sementara dari aspek pembelajaran oleh guru adalah guru memberikan materi IPA dengan metode ceramah, model pembelajaran yang digunakan kurang memotivasi siswa, tidak melibatkan siswa dalam proses pembelajaran secara langsung dan masih bersifat teacher center. Sedangkan pada aktivitas siswa yang diamati adalah ketika proses belajar dan pembelajaran sedang berlangsung siswa-siswa tidak terlalu peduli dan kurang merespon ketika guru memberi pertanyaan. Selain itu ketika proses belajar sedang berlangsung masih ada beberapa siswa yang ribut di dalam kelas dan melakukan aktivitas lain diluar konteks belajar, seperti mengobrol, bercanda dan keluar masuk kelas. Rendahnya motivasi dan aktivitas siswa 
sejalan dengan rendahnya hasil belajar siswa.

Pada proses pembelajaran sebelumnya, guru masih sangat jarang mengarahkan siswa untuk mengkaitkan materi pembelajaran dengan masalah nyata di kehidupan sehari-hari. Apabila guru mampu merangsang siswa untuk mengaitkan setiap materi dengan masalah nyata bukan hal yang tidak mungkin siswa menjadi mampu berfikir kreatif, imajinatif, dan mampu mengembangkan pengetahuannya dalam dunia nyata.

Menurut Rusman (2014) guru dituntut dapat memilih model pembelajaran yang dapat memacu semangat setiap siswa untuk secara aktif ikut terlibat dalam pengalaman belajarnya. Salah satu alternatif model pembelajaran yang memungkinkan dikembangkannya keterampilan berpikir siswa (penalaran, komunikasi, dan koneksi) dalam memecahkan masalah adalah Model Problem Based Learning (PBL).

Menurut Hosnan (2014) model PBL bercirikan penggunaan masalah kehidupan nyata sebagai sesuatu yang harus dipelajari siswa untuk melatih dan meningkatkan keterampilan berpikir kritis dan pemecahan masalah serta mendapatkan pengetahuan konsepkonsep penting, dimana tugas guru harus memfokuskan diri untuk membantu siswa mencapai keterampilan mengarahkan diri.

Oleh karena itu, dalam penelitian ini tindakan yang dipilih untuk memperbaiki pembelajaran oleh guru agar masalah pada siswa dapat teratasi adalah dengan menerapkan model pembelajaran Problem Based Learning (PBL) pada materi Dampak Pencemaran Bagi Kehidupan untuk meningkatkan aktivitas dan hasil belajar siswa. Dengan penggunaan model pembelajaran Problem Based Learning (PBL) diharapkan siswa dapat berpartisipasi secara aktif dalam menemukan konsep pelajaran, sehingga pengetahuan yang didapat berdasarkan pengalaman itu akan lebih bertahan lama dan bisa meningkatkan hasil belajar siswa dan juga agar dapat menekankan pada pengembangan aspek kognitif siswa.

Kesesuaian model Problem Based Learning (PBL) dengan kondisi pembelajaran yang dihadapi berdasarkan pada hasil penelitian sebelumnya. Menurut Effendi (2016) model pembelajaran berdasarkan masalah (Problem Based Learning) dapat meningkatkan aktivitas dan hasil belajar siswa. Widodo (2013) menyatakan bahwa PBL dapat meningkatkan aktivitas belajar siswa kelas VIIA di MTs Donomulyo, Nanggulan, Kulon Progo pada pokok bahasan Wujud Zat dan Perubahannya. Penelitian Parasamya dan Wahyuni (2017) juga menunjukkan bahwa berdasarkan hasil penelitian dan analisis data pada penelitian tindakan kelas (PTK) yang telah dilaksanakan selama 3 siklus terlihat adanya peningkatan hasil belajar, aktivitas guru dan siswa, kemampuan guru dalam mengelola pembelajaran, dan respon siswa yang baik terhadap penerapan model pembelajaran Problem Based Learning (PBL).

Tidak semua materi IPA cocok menggunakan pembelajaran model PBL. Menurut penelitian yang dilakukan oleh Harahap dan Prastowo (2014), diketahui bahwa model PBL cocok digunakan pada materi Pencemaran Lingkungan dan Upaya Mengatasinya. Penerapan model PBL pada materi Pencemaran Lingkungan dan Upaya Mengatasinya diharapkan dapat menimbulkan komunikasi yang baik diantara siswa karena siswa dapat saling berbagi ide dan pendapat, saling mendiskusikan masalah-masalah yang ada pada lingkungan sehingga mereka lebih mudah menemukan dan mengemukakan ide atau solusi dalam penyelesaian masalah yang ada di lingkungan. Selain 
itu, siswa juga dapat berperan aktif dalam proses belajar mengajar, serta terbiasa berpikir secara kritis.

Berdasarkan data dan informasi di atas, maka peneliti dan guru melakukan perbaikan pembelajaran di kelas $\mathrm{VII}_{2}$ melalui penelitian tindakan kelas dengan judul "Penerapan Model Problem Based Learning ( $\mathrm{PBL}$ ) Untuk Meningkatkan Aktivitas Dan Hasil Belajar IPA Siswa Kelas $\mathrm{VII}_{2}$ Pada Materi Dampak Pencemaran Bagi Kehidupan Di SMPN 14 Kota Bengkulu". Rumusan masalah dalam penelitian ini adalah : 1) Bagaimana aktivitas mengajar guru dan aktivitas belajar siswa kelas $\mathrm{VII}_{2}$ SMPN 14 Kota Bengkulu pada materi Dampak Pencemaran bagi Kehidupan dengan penerapan model Problem Based Learning (PBL)?, 2) Bagaimana hasil belajar IPA siswa kelas $\mathrm{VII}_{2}$ SMPN 14 Kota Bengkulu pada materi Dampak Pencemaran bagi Kehidupan dengan penerapan model Problem Based Learning (PBL) ?. Sedangkan tujuan penelitian ini adalah : 1) Untuk mendeskripsikan aktivitas mengajar guru dan aktivitas belajar siswa dengan penerapan model Problem Based Learning (PBL) pada materi Dampak Pencemaran bagi Kehidupan di kelas $\mathrm{VII}_{2}$ SMPN 14 Kota Bengkulu, 2) Untuk mendeskripsikan hasil belajar IPA siswa dengan penerapan model Problem Based Learning (PBL) pada materi Dampak Pencemaran bagi Kehidupan di kelas $\mathrm{VII}_{2}$ SMPN 14 Kota Bengkulu.

Secara praktis penelitian ini bermanfaat bagi siswa, guru, peneliti dan sekolah. Manfaat bagi siswa yaitu dapat belajar menemukan konsep dengan menggunakan model pembelajaran Problem Based Learning (PBL). Manfaat bagi guru yaitu dapat menambah ilmu dan pembelajaran mengenai penerapan model Problem Based Learning (PBL) dan memberikan alternatif lain bagi guru tentang model pembelajaran yang dapat digunakan dalam proses belajar mengajar. Manfaat bagi peneliti yaitu dapat menjadi terampil dan menambah pengetahuan tentang pembelajaran terutama tentang penerapan model pembelajaran Problem Based Learning (PBL). Manfaat bagi sekolah yaitu dapat mengembangkan proses pembelajaran dengan menggunakan model pembelajaran Problem Based Learning (PBL).

\section{METODE}

Jenis penelitian yang digunakan yaitu Penelitian Tindakan Kelas (PTK). Sedangkan metode yang digunakan dalam penelitian ini adalah metode deskriptif. Subjek penelitian ini adalah seluruh siswa kelas VII 2 SMPN 14 Kota Bengkulu tahun ajaran 2016/2017 yang berjumlah 34 orang, yang terdiri dari 17 orang laki-laki dan 17 orang perempuan. Teknik pengumpulan data yang digunakan dalam penelitian ini ada 2 cara, yaitu dengan observasi dan tes. Di dalam PTK terdiri dari dua siklus, setiap siklus terdiri dari empat tahap yakni perencanaan, pelaksanaan, pengamatan, dan refleksi.

Aktivitas mengajar guru dan aktivitas belajar siswa dideskripsikan melalui deskripsi data kuantitatif penelitian melalui analisis proses pembelajaran yang dilakukan. Analisis data observasi dilakukan dengan cara menghitung rerata skor pengamat menggunakan rumus :

a. Rata-rata skor $=\frac{\text { jumlah } \text { skor }}{\text { jumlah pengamat }}$

b. Skor tertinggi = jumlah butir pengamatan $\mathrm{x}$ skor tertinggi tiap butir pengamatan

c. Skor terendah = jumlah butir pengamatan $\mathrm{x}$ skor terendah tiap butir pengamatan

d. Selisih skor $=$ skor tertinggi - skor terendah 
e. Kisaran nilai tiap kriteria = selisih skor jumlah kriteria penilaian

(Arikunto, 2012)

Hasil belajar siswa dideskripsikan melalui deskripsi data hasil belajar siswa melalui pemberian tes hasil belajar. Tes hasil belajar diperoleh dari setiap siklus dan dianalisis secara deskriptif untuk mengetahui nilai rata-rata hasil belajar dan persentase ketuntasan belajar klasikal. Nilai rata-rata hasil belajar siswa dihitung menggunakan rumus:

$\mathrm{X}=\frac{\Sigma x}{N}$

Keterangan:

$\mathrm{X}=$ Nilai rata-rata kelas

$\Sigma \mathrm{X}=$ Jumlah nilai siswa keseluruhan

$\mathrm{N} \quad=$ Jumlah seluruh siswa

Untuk menganalisis data hasil belajar siswa secara keseluruhan maka dihitung ketuntasan belajar klasikal menggunakan rumus (Trianto, 2011) :

$\mathrm{KB}=\frac{N S}{N} \times 100 \%$

Keterangan:

$\mathrm{KB}=$ ketuntasan belajar klasikal

NS =jumlah siswa yang memperoleh nilai $\geq 75$

$\mathrm{N} \quad$ = jumlah seluruh siswa

\section{HASIL DAN PEMBAHASAN}

Berdasarkan penelitian yang telah dilaksanakan di kelas $\mathrm{VII}_{2}$ SMPN 14 Kota Bengkulu pada minggu pertama bulan April 2017 dengan menerapkan model pembelajaran Problem Based Learning (PBL) sebanyak 2 siklus berfokus pada aktivitas mengajar guru, aktivitas belajar siswa dan hasil belajar siswa pada materi Dampak Pencemaran Bagi kehidupan, diperoleh hasil sebagai berikut ini:

Siklus I

\section{Deskripsi Hasil Observasi Aktivitas Guru pada Siklus 1}

Pada siklus 1 dilakukan observasi aktivitas mengajar guru terhadap proses pembelajaran IPA dengan menggunakan model pembelajaran Problem Based Learning (PBL) yang dilakukan oleh 3 orang pengamat yaitu guru IPA SMPN 14 Kota Bengkulu dan dua calon guru. Hasil dari observasi aktivitas guru dapat dilihat pada Tabel 1 berikut ini:

Tabel 1. Data Hasil Observasi Aktivitas Guru pada Siklus 1

\begin{tabular}{lcc}
\hline No & Pengamat & Skor \\
\hline 1. & I & 30 \\
2. & II & 30 \\
3. & III & 31 \\
Total Skor & 91 \\
Rerata Skor & 30,3 \\
Kriteria & Baik \\
\hline
\end{tabular}

Berdasarkan Tabel 1 dapat diketahui bahwa aktivitas guru dalam pembelajaran memperlihatkan kriteria baik. Hal ini dapat dilihat dari dari skor rata-rata dari 3 orang pengamat yaitu 30,3 dengan kriteria baik (B).

\section{Deskripsi Hasil Observasi Terhadap Aktivitas Belajar Siswa pada Siklus I}

Pengamatan terhadap aktivitas belajar siswa pada siklus I dilakukan oleh 3 orang pengamat yaitu guru IPA SMPN 14 Kota Bengkulu dan dua calon guru dengan menggunakan lembar observasi siswa. Perolehan skor rata-rata untuk aktivitas siswa dapat dilihat pada Tabel 2.

Tabel 2. Data Hasil Observasi Terhadap Aktivitas Siswa pada Siklus I

\begin{tabular}{ccc}
\hline No & Pengamat & Skor \\
\hline 1. & I & 30 \\
2. & II & 31 \\
3. & III & 30 \\
\hline
\end{tabular}




\begin{tabular}{lc}
\hline Total Skor & 91 \\
Rerata Skor & 30,3 \\
Kriteria & Baik \\
\hline
\end{tabular}

Berdasarkan Tabel 2 diketahui bahwa perolehan skor dari 3 pengamat adalah sebesar 91 dengan rata-rata skor 30,3. Rata-rata skor tersebut menunjukkan bahwa aktivitas siswa selama proses pembelajaran dengan menerapkan model pembelajaran Problem Based Learning (PBL) termasuk dalam kriteria baik (B).

\section{Deskripsi Hasil Belajar}

Hasil belajar pengetahuan diperoleh melalui penilaian yang dilakukan dalam bentuk pemberian tes tertulis pada akhir pembelajaran (postest) berupa 10 soal pilihan ganda dengan 4 pilihan jawaban. Analisis persentase ketuntasan hasil belajar klasikal siswa siklus I dapat dilihat pada Tabel 3.

Tabel 3. Ketuntasan Belajar Klasikal Siswa pada Siklus I

\begin{tabular}{cccccc}
\hline $\begin{array}{c}\mathbf{N} \\
\text { (orang) }\end{array}$ & $\begin{array}{c}\text { Nilai } \geq 75 \\
\text { (orang) }\end{array}$ & $\Sigma \mathbf{X}$ & $\mathbf{X}$ & $\begin{array}{c}\text { KB } \\
\text { (\%) }\end{array}$ & Kriteria \\
\hline 34 & 28 & 2800 & 82,3 & 82,3 & $\begin{array}{c}\text { Tidak } \\
\text { tuntas }\end{array}$ \\
\hline
\end{tabular}

Keterangan:

$\mathrm{N}$ : Jumlah seluruh siswa

$\mathrm{X}$ : Nilai rata-rata kelas

$\Sigma X$ : Jumlah nilai keseluruhan siswa

KB : Persentase ketuntasan belajar

Berdasarkan Tabel 3 dapat diketahui bahwa persentase ketuntasan belajar pada siklus I adalah 82,3\% termasuk kriteria tidak tuntas dimana dari jumlah keseluruhan siswa yaitu 34 orang siswa hanya sebanyak 28 orang saja yang mendapatkan nilai $\geq 75$. Berdasarkan kriteria ketuntasan minimal (KKM) yang telah ditetapkan oleh SMPN 14 Kota Bengkulu bahwa pembelajaran dikatakan tuntas secara individual apabila siswa memperoleh nilai $\geq 75$ yang dapat dilihat dari hasil tes siswa. Sedangkan proses pembelajaran dikatakan tuntas secara klasikal apabila $85 \%$ siswa dikelas memperoleh nilai $\geq 75$. Berdasarkan hasil analisis di atas pembelajaran pada siklus I dengan menerapkan model PBL ini belum mendapatkan hasil yang maksimal yaitu masih banyak kekurangan yang harus diperbaiki ketika proses pembelajaran berlangsung seperti yang telah dijelaskan pada hasil observasi terhadap aktivitas guru dan aktivitas siswa.

\section{Siklus II}

\section{Deskripsi Hasil Observasi Aktivitas Guru pada Siklus II}

Pada kegiatan siklus II dilakukan observasi aktivitas mengajar guru terhadap proses pembelajaran IPA dengan menggunakan model pembelajaran Problem Based Learning (PBL) yang dilakukan oleh 3 orang pengamat yaitu guru IPA SMPN 14 Kota Bengkulu dan dua calon guru. Hasil dari observasi aktivitas guru dapat dilihat pada Tabel 4.

\begin{tabular}{lcc} 
Tabel & 4. & $\begin{array}{c}\text { Data } \\
\text { Aktivitas Guru pada Siklus II }\end{array}$ \\
\hline No & Pengamat & Skor \\
\hline 1. & I & 31 \\
2. & II & 31 \\
3. & III & 31 \\
Total Skor & 93 \\
Rerata Skor & 31 \\
Kriteria & Baik \\
\hline
\end{tabular}

Berdasarkan Tabel 4 dapat diketahui bahwa aktivitas guru dalam pembelajaran memperlihatkan kriteria baik. Hal ini dapat dilihat dari dari skor rata-rata dari 3 orang pengamat yaitu 31 dengan kriteria baik (B).

Deskripsi Hasil Observasi Terhadap Aktivitas Belajar Siswa pada Siklus II 
Pengamatan terhadap aktivitas belajar siswa pada siklus II dilakukan oleh 3 orang pengamat yaitu guru IPA SMPN 14 Kota Bengkulu dan dua calon guru dengan menggunakan lembar observasi siswa. Perolehan skor rata-rata untuk aktivitas siswa dapat dilihat pada Tabel 5.

Tabel 5. Data Hasil Observasi Terhadap Aktivitas Siswa pada Siklus II

\begin{tabular}{lcc}
\hline No & Pengamat & Skor \\
\hline 1. & I & 30 \\
2. & II & 31 \\
3. & III & 31 \\
Total Skor & 92 \\
Rerata Skor & 30,6 \\
Kriteria & Baik \\
\hline
\end{tabular}

Berdasarkan Tabel 5 diketahui bahwa perolehan skor dari 3 pengamat adalah sebesar 92 dengan rata-rata 30,6. Rata-rata skor tersebut menunjukkan bahwa aktivitas siswa selama proses pembelajaran dengan menerapkan model pembelajaran Problem Based Learning (PBL) termasuk dalam kriteria Baik (B).

\section{Deskripsi Hasil Belajar}

Hasil belajar pengetahuan diperoleh melalui penilaian yang dilakukan dalam bentuk pemberian tes tertulis pada akhir pembelajaran (postest) berupa 10 soal pilihan ganda dengan 4 pilihan jawaban. Analisis persentase ketuntasan hasil belajar klasikal siswa siklus II dapat dilihat pada Tabel 6 .

Tabel 6. Ketuntasan Belajar Klasikal Siswa pada Siklus II

\begin{tabular}{|c|c|c|c|c|c|}
\hline $\begin{array}{c}N \\
\text { (orang) }\end{array}$ & $\begin{array}{c}\text { Nilai } \geq 75 \\
\text { (orang) }\end{array}$ & $\sum X$ & $X$ & $\begin{array}{c}\text { KB } \\
(\%)\end{array}$ & Kriteria \\
\hline 34 & 29 & 2950 & 86,7 & 85,2 & Tuntas \\
\hline
\end{tabular}

Keterangan:

$\mathrm{N}$ : Jumlah seluruh siswa

$\mathrm{X}$ : Nilai rata-rata kelas
$\Sigma \mathrm{X}$ : Jumlah nilai keseluruhan siswa

KB : Persentase ketuntasan belajar

Berdasarkan Tabel 6 dapat diketahui bahwa pada hasil belajar pengetahuan, jumlah siswa yang memperoleh nilai $\geq 75$ adalah sebanyak 29 orang siswa dari 34 orang siswa yang mengikuti tes dengan persentase ketuntasan belajar secara klasikal 85,2\%. Hal ini menunjukkan bahwa pembelajaran yang telah dilaksanakan pada siklus II sudah mencapai kriteria tuntas dengan persentase ketuntasan belajar klasikal pada siklus II telah mencapai $85 \%$ dan sesuai dengan Kriteria Ketuntasan Minimal (KKM) mata pelajaran IPA di SMPN 14 Kota Bengkulu.

Berdasarkan hasil penelitian, kegiatan pembelajaran yang telah dilakukan oleh guru selama dua siklus dengan menerapkan model pembelajaran Problem Based Learning (PBL) pada kelas $\mathrm{VII}_{2}$ SMPN 14 Kota Bengkulu terjadi peningkatan pada siklus II. Hal ini ditunjukkan dari adanya peningkatan rerata skor observasi aktivitas guru, aktivitas siswa, dan hasil belajar siswa pada siklus II. Peningkatan pembelajaran yang terjadi pada siklus II ini diperoleh karena adanya refleksi proses pembelajaran pada siklus I. Hasil refleksi ini terlihat dari peningkatan serta perubahan pada pembelajaran dari siklus I ke siklus II, baik itu pada aktivitas guru dan aktivitas siswa, maupun hasil belajar siswa.

Dengan merefleksi pembelajaran siklus I, dilakukan perbaikan proses pembelajaran. Perbaikan proses pembelajaran yang dilakukan oleh peneliti yaitu dimulai dari aktivitas guru, aktivitas siswa serta hasil belajar siswa sehingga diperoleh hasil belajar yang diinginkan. Hal ini sejalan dengan yang dikemukakan oleh Hosnan (2014) bahwa tujuan 
pembelajaran adalah membantu siswa agar memperoleh berbagai pengalaman dan mengubah tingkah laku siswa, baik dari segi kualitas maupun kuantitas. Perubahan tingkah laku yang dimaksud meliputi pengetahuan, keterampilan dan nilai atau norma yang berfungsi sebagai pengendali sikap dan prilaku siswa.

Menurut Rusman (2014), pembelajaran hendaknya menitikberatkan pada aktivitas siswa dengan cara memberikan kesempatan seluas-luasnya untuk beraktivitas dan berkreativitas dalam mengembangkan potensinya menuju tingkat yang lebih dewasa. Dengan proses belajar yang menekankan pada aktivitas siswa, pembelajaran menjadi lebih bermakna serat nilai dan lebih humanis dalam mengembangkan kepribadian siswa secara menyeluruh. Karena dengan proses belajar tersebut siswa mendapatkan pengalaman langsung secara kontekstual.

Pada dasarnya proses pembelajaran merupakan suatu proses interaksi antara guru dengan siswa. Peranan guru pada proses pembelajaran ini adalah untuk membangkitkan semangat siswa sehingga siswa termotivasi untuk berperan aktif pada proses pembelajaran yang berlangsung. Dalam proses pembelajaran, semangat dan motivasi yang diberikan guru kepada siswa dapat dikatakan sebagai daya penggerak di dalam diri siswa sehingga diharapkan tujuan pembelajaran yang diterapkan oleh guru dapat tercapai oleh siswa.

Untuk mengetahui tingkat keberhasilan siswa selama mengikuti proses pembelajaran menggunakan model pembelajaran Problem Based Learning (PBL), guru memberikan evaluasi berupa test tertulis dalam bentuk post test dengan kategori soal yaitu 10 soal pilihan ganda dengan 4 pilihan jawaban. Menurut Arifin (2012) guru perlu melakukan penilaian hasil belajar setelah peserta didik mengikuti proses belajar yang didasarkan atas kriteria tertentu. Setelah ditetapkan kriterianya, guru baru dapat menentukan berhasil tidaknya peserta didik, baik dalam proses maupun hasil belajarnya. Berdasarkan hasil penelitian yang telah dilakukan dengan penerapan model pembelajaran Problem Based Learning (PBL) dapat disimpulkan bahwa terjadi peningkatan hasil belajar siswa pada siklus II. Peningkatan hasil belajar siswa tersebut dapat dilihat pada Gambar 2.

Persentase ketuntasan belajar klasikal pada siklus I yaitu $82,3 \%$ dan dikategorikan belum tuntas. Sedangkan ketuntasan belajar klasikal siswa pada siklus II yaitu $85,2 \%$ dan dikategorikan tuntas karena telah mencapai kriteria ketuntasan belajar klasikal yang ditentukan oleh sekolah SMPN 14 Kota Bengkulu yaitu sebesar 85\%. Sehingga, dapat disimpulkan penerapan model pembelajaran Problem Based Learning (PBL) pada proses pembelajaran materi dampak pencemaran bagi kehidupan dapat meningkatkan hasil belajar siswa. Hal tersebut dikarenakan adanya peningkatan hasil belajar siswa dari siklus I dengan ketuntasan belajar klasikal 82,3\% meningkat menjadi $85,2 \%$ pada siklus II.

\section{PENUTUP}

\section{Simpulan}

Berdasarkan Penelitian Tindakan Kelas (PTK) yang telah dilakukan dapat ditarik kesimpulan sebagai berikut:

1. Perbaikan pembelajaran dikelas $\mathrm{VII}_{2}$ SMPN 14 Kota Bengkulu dengan menerapkan model pembelajaran Problem Based Learning (PBL) dalam proses pembelajaran pada materi "Dampak Pencemaran Bagi Kehidupan" dapat meningkatkan aktivitas mengajar guru yaitu dengan rerata skor 30,3 pada siklus I 
meningkat menjadi 31 pada siklus II dan aktivitas belajar siswa dengan rerata skor 30,3 pada siklus I meningkat menjadi 30,6 pada siklus II.

2. Perbaikan pembelajaran dikelas $\mathrm{VII}_{2}$ SMPN 14 Kota Bengkulu dengan menerapkan model pembelajaran Problem Based Learning (PBL) dalam proses pembelajaran pada materi "Dampak Pencemaran Bagi Kehidupan" dapat meningkatkan hasil belajar siswa dengan nilai rata-rata kelas 82,3 pada siklus I meningkat menjadi 86,7 pada siklus II dan persentase ketuntasan belajar klasikal $82,3 \%$ pada siklus I dan meningkat menjadi $85,2 \%$ pada siklus II.

\section{Saran}

Berdasarkan Penelitian Tindakan Kelas (PTK) yang telah dilakukan, beberapa saran yang dapat dianjurkan yaitu:

1. Diharapkan kepada peneliti sebaiknya harus lebih memahami sintaks dari model pembelajaran Problem Based Learning (PBL) agar setiap kegiatan pembelajaran/proses pembelajaran yang dilakukan dapat berjalan dengan lancar, sehingga mendapatkan hasil yang baik dan sesuai dengan yang diinginkan.

2. Diharapkan kepada guru mata pelajaran IPA kelas $\mathrm{VII}_{2}$ SMPN 14 Kota Bengkulu dapat menggunakan model pembelajaran Problem Based Learning (PBL) sebagai salah satu alternatif dalam pembelajaran untuk diterapkan pada pembelajaran IPA sebagai salah satu upaya meningkatkan hasil belajar siswa.

\section{DAFTAR PUSTAKA}

Arifin, Zainal. 2012. Evaluasi Pembelajaran. Bandung: PT Remaja Rosdakarya
Arikunto, Suharsimi. 2012. Dasar-Dasar Evaluasi Pendidikan. Jakarta: PT Bumi Aksara

Effendi, M. 2016. Peningkatan Aktivitas Dan Hasil Belajar Matematika Melalui Model Pembelajaran Berdasarkan Masalah (Problem Based Learning) Pada Peserta Didik Kelas VI SDN 04 Nan Sabaris Tahun Pelajaran 2015/2016. http://jurnal.konselingindonesia. com/index.php/jkp/article/view/ 63/67 (diakses tanggal 23 Januari 2017)

Harahap, M. A. dan Prastowo, P. 2014. Perbedaan Hasil Belajar Siswa Yang Diajar Menggunakan Model Pembelajaran Project Based Learning Dengan Problem Based Learning Pada Materi Pencemaran

Lingkungan.http://digilib.unimed. ac.id/4828/1/Fulltext.pdf (diakses tanggal 23 Januari 2017)

Hosnan, M. 2014. Pendekatan Saintifik dan Kontekstual dalam Pembelajaran Abad 21. Bogor: Ghalia Indonesia

Kunandar. 2013. Langkah Mudah Penelitian Tindakan Kelas Sebagai Pengembangan Profesi Guru. Jakarta: PT. Raja Grafindo Persada

Parasamya, C. E. dan Wahyuni, A. 2017. Upaya Peningkatan Hasil Belajar Fisika Siswa Melalui Penerapan Model Pembelajaran Problem Based Learning (PBL). http://www.jim.unsyiah.ac.id/pe ndidikan-

fisika/article/view/2145/1106 (diakses tanggal 23 Januari 2017)

Permendikbud. 2014. Peraturan Menteri Pendidikan dan Kebudayaan Republik Indonesia Nomor 58 Tahun 2014 Tentang Kurikulum 
2013 Sekolah Menengah

Pertama/ Madrasah Tsanawiyah.

Jakarta: Depdiknas

Permendikbud. 2014. Peraturan Menteri

Pendidikan Dan Kebudayaan

Republik Indonesia Nomor 103

Tahun 2014 Tentang Pembelajaran

Pada Pendidikan Dasar Dan

Pendidikan Menengah. Jakarta:

Depdiknas

Rusman. 2014. Model - model Pembelajaran mengembangkan Profesionalisme Guru Edisi Kedua. Jakarta : Rajawali Pers

Suyadi. 2012. Buku Panduan Guru Profesional Penelitian Tindakan Kelas (PTK) dan Penelitian Tindakan Sekolah (PTS). Yogyakarta: ANDI

Trianto. 2011. Model Pembelajaran Terpadu. Jakarta: Bumi Aksara

Widodo, L. W. 2013. Peningkatan Aktivitas Belajar dan Hasil Belajar Siswa Dengan Metode Problem Based Learning Pada Siswa Kelas VIIA Mts Negeri Donomulyo Kulon Progo Tahun Pelajaran 2012/2013. Jurnal Fisika Indonesia, 17(49): hlm. 32-35. (Online)(http://pdmmipa.ugm.ac. id/ojs/index.php/jfi/article/downl oad/831/910) (diakses tanggal 23 Januari 2017) 